\title{
Analysis of Economic Efficiency in Sawnwood Production in Southwest Nigeria
}

\author{
A.L. Kehinde*1 and T.T.Awoyemi ${ }^{2}$ \\ 1. Department of Agricultural Economics and Extension, Bowen University, P.M.B. 284, \\ Iwo, Osun State, Nigeria \\ Telephone: 2348037860000,E-mail: tjgreenk@yahoo.com \\ 2. Department of Agricultural Economics, University of Ibadan, Nigeria
}

KEYWORDS Technical and Allocative Efficiency. Sawnwood Producers. Resource Savings

\begin{abstract}
This paper deals with the issue of improving economic efficiency in sawnwood production in Ondo and Osun states, southwest Nigeria. The stochastic frontier approach was used to estimate a self dual Cobb Douglas production function which gave estimates of technical, allocative and economic efficiencies. In a second stage analysis, the ordinary least square regression method was used to estimate the determinants of the observed inefficiencies. Cross sectional data was obtained from 170 sawnwood producers using a two stage sampling procedure. Results indicate that the mean technical, allocative and economic efficiencies of sawnwood producers in Ondo and Osun states are $68 \%, 81 \%$ and $54 \%$ and $79 \%, 83 \%$ and $67 \%$, respectively. Furthermore, sawmillers' level of efficiency can be improved if sawlog, electricity and capital are effectively used in Ondo state while the same can be achieved if sawlog is efficiently used in Osun state. Managerial type, capital base and capacity utilization deserve attention in order to improve the present efficiency level of sawmillers. The study recommends that the observed inefficiencies be addressed if producers are to achieve significant resource savings.
\end{abstract}

\section{INTRODUCTION}

Efficiency in natural resource use is now a common talk. In the tropical forest the fast diminishing quantity of merchantable timber has made the idea of efficient timber use an attractive approach of helping to reduce waste that has hitherto characterized wood processing in Nigeria. It is noteworthy that timber is strategic in its multifaceted use for energy supply, construction and environmental protection among others. As a renewable environmental good, the challenge of meeting timber supply globally depends largely on forest management system which operates in different regions of the world. The issue of efficiency therefore becomes central and relevant in achieving sustainability of the forest industries.

The forest sector is unique in the challenges that confront it. For example it takes a felling cycle of 50 years for most timber species to arrive at a merchantable size (Dykstra et al. 1996), institutional shortcomings have allowed massive

Corresponding Author:

A.L. Kehinde, Department of Agricultural Economics and Extension, Bowen University, P.M.B. 284, Iwo, Osun State, Nigeria

Telephone: 2348037860000

E-mail:tjgreenk@yahoo.com illegal harvesting regimes in the free and government's forest areas in Nigeria; improper pricing of timber has discouraged investment in timber production; weak political will has debarred judiciously use of deductions for the regeneration of timber (Olaseni et al. 2004). These are major disincentive to increasing the productivity of timber; a major resource in sawnwood production.

One may be quick to think that eliminating the aforementioned constraints would necessarily improve sawnwood production efficiency. However, it should be noted that any effort directed towards improving sawnwood production at sawmills would concern its self with two very important issues. One, it must be determined whether sawnwood productivity can be increased by reorganizing and efficiently utilizing resources at sawmills and two, whether an outright introduction of new technology would be necessary to improve sawnwood production efficiency. Though Noack (1995) argued that better wood utilization efficiency at mills can greatly improve the sustainability of tropical timber industry but it still remains for this study to utilize the concept of economic efficiency to estimate efficiency of sawnwood production at sawmills.

The modeling of efficiency by specifying a self dual production function as originally 
proposed by Aigner et al. (1977) and Meeusen and Van den Broeck (1977). It is an important aspect of economic analysis that can be used to capture efficiency estimates of producers by considering output and inputs at a particular state of technology. Economic efficiency as a concept embodies technical and allocative efficiencies. It is conditional that sawmills must both achieve technical and allocative efficiencies in other to be economically efficient. The attainment of technical efficiency ensures that optimal utilization of production inputs is achieved. It can be a useful tool to government in helping to achieve forest resource sustainability by ensuring optimal timber use and reduced pressure on the fast depleting tropical forest. The idea of technical efficiency can also provide an index for forest managers in the determination of annual allowable cut of timber (Gunatilake and Gunaratne, 2002). Achieving allocative efficiency will ensure that sawmillers make optimal pricing decisions on the use of production inputs. Several researchers have utilized this approach extensively in agriculture while its use is still limited in forest studies. Examples of its use in agriculture include, Chavas and Aliber (1993), Sharma et al. (1999) and Shafiq and Rehman (2000).

To this end, the objective of the study are (1) to determine the technical, allocative and economic efficiencies of sampled sawnwood producers (2) to identify the effects of producers specific factors on technical, allocative and economic efficiencies of sawnwood producers.

\section{METHODOLOGY}

\section{Study Area}

The study was carried out in the southwestern agroecological zone of Nigeria because active logging, wholesale and retail selling of sawnwood take place here. The southwestern zone of Nigeria comprises mainly the rainforest vegetation belt. Some common sawnwood species in this zone include Triplochiton seleroxylon, Masonia altissima, Khaya ivorensis, Milicia excelsa, Terminalia superba, Afzelia Africana, Terminalia ivorensis, Cedrela odorata, Cordia milenii, Mitragyna ciliate, Nesorgodonia papaverifera, Nauclea diderichii, Brachystegia eurycoma. The southwestern zone comprises Oyo, Osun, Ondo, Ekiti, Ogun and Lagos states. Ondo and Osun states were purposively selected because the two states are geographically contiguous.

\section{Sampling Technique}

A two stage random sampling technique was adopted to select representative sawmills from 238 and 245 sawmills in Ondo and Osun states respectively (Ondo State Ministry of Finance and Osun state Forestry Departments 2002). The first stage involved a random selection of local government areas (LGAs) using a sampling fraction of 0.25 . Five LGAs were selected out of the 18 sawnwood producing LGAs in Ondo state, namely; Akure-north, Akure-south, Odigbo, Ondo west and Owo. Likewise seven LGAs were selected out of the 29 sawnwood producing LGAs in Osun, viz; Iwo, Isokan, Ayedade, Irewole, Ifecentral, Ejigbo and Ede-north. The second stage of sampling involved a random selection of sawmills from the five LGAs in Ondo and the seven LGAs in Osun states using a sampling fraction of 0.35 in other to obtain a statically large sample. A sampling population of 83 and 87 sawmills was obtained in Ondo and Osun states, respectively. A total population of 170 sawmills was sampled in all using questionnaires to obtain information from sawnwood producers.

\section{Analytical Framework}

Technical, Allocative and Economic Efficiency of Sawmillers: The stochastic production function based on parametric stochastic efficiency decomposition methodology was used to estimate the technical, allocative and economic efficiency measures of sawmills following BravoUreta (1993), Sharma et al. (1999), Aigner et al. (1977), Meeusen and Van den Broeck (1977). The maximum likelihood estimates of the parameters of the stochastic production frontier model was obtained using the frontier command of the LIMDEP (Limited Dependent variable) software version 7 (copyright 1985 - 1997). The concept of technical efficiency relates to the question of whether a firm uses the best available technology in its production process. It is assumed that $0<$ technical efficiency $<1$, where technical efficiency $=1$ implies that the firm is producing on its production frontier and is said to be technically efficient. 1 - technical efficiency is therefore the largest proportional reduction in input that can 
be achieved in the production of the output. Alternatively it can be interpreted as the largest percentage cost saving that can be achieved by moving the firm towards the frontier isoquant through radial rescaling of all inputs (Chavas and Aliber 1993).

According to Farrell (1957) and Farrell and Fieldhouse (1962), the concept of allocative efficiency is related to the ability of a firm to choose its input in a cost minimizing way. It reflects whether a technically efficient firm produces at the least possible cost. It is generally assumed that, $0<$ allocative efficiency $<1$, where the firm is said to be allocatively efficient. Following the same line of reasoning, 1 allocative efficiency measures the maximal proportion of cost the technical efficient firm can save by behaving in a cost minimizing way. The Cobb Douglas cost function was specified for this purpose. The maximum likelihood estimates of the stochastic cost frontier using the frontier command of LIMDEP software version 7 was estimated for sawmills in Ondo and Osun states. The product of the technical efficiency (T.E) and the allocative efficiency (A.E) indices gives the economic efficiency $($ E.E) index i.e $($ T.E*A.E $)=$ E.E. It is assumed that $0<($ T.E*A.E $)<1$. Therefore $($ T.E*A.E) $=1$ implies that a sawmill is both technically and allocatively efficient. Alternatively, (T.E*A.E) $<1$ indicates that a sawmill is not efficient, $[1-($ T.E*A.E) $]$ measures the proportional reduction in cost that sawmills can achieve by becoming technically and allocatively efficient.

Assume a stochastic production frontier:

$\mathrm{Y}_{\mathrm{i}}=\mathrm{g}\left(\mathrm{X}_{\mathrm{i}}, \beta_{\mathrm{i}}\right) \exp \left(\mathrm{V}_{\mathrm{i}}-\mathrm{U}_{\mathrm{i}}\right)$

Where, $\mathrm{i}$ is $1,2, . .4$; $\mathrm{J}$ is $1,2, \ldots \ldots \ldots \ldots, 170$; $\mathrm{Y}_{\mathrm{j}}$ is sawnwood output $\left(\mathrm{m}^{3}\right) ; X_{i}$ is inputs; $\beta_{i}$ is parameter to be estimated; $\mathrm{V}_{\mathrm{i}}$ is random error due to misspecification of model; $U_{i}$ is Inefficiency component of error term and $\mathrm{g}()=.\mathrm{A} \mathrm{Cobb}$ Douglas function.

The Cobb Douglas model was used to fit stochastic production frontiers for sawmills using the maximum likelihood technique. The functional form has been widely used in farm efficiency analyses for both developing and developed countries (Bravo-Ureta and Evenson, 1994). Further, the use of the single equation model was justified by assuming that sawmillers maximize expected profit as is commonly done in studies of this nature (Zellner et al. 1966, Kopp and Smith, 1980). The specific model is explicitly written as:
$\operatorname{Ln} Y_{j}=\beta_{0}+\beta_{1} \operatorname{Ln} X_{1}+\beta_{2} \operatorname{LnX}_{2}+\beta_{3} \operatorname{LnX}_{3}+$ $\beta_{4} \operatorname{LnX}_{4}+\beta_{5} \operatorname{LnX}+\mathrm{e}_{\mathrm{i}} \ldots \ldots \ldots \ldots . . . .(2)$

$X_{1}<0, X_{2}>0, X_{3}>0, X_{4}>0, X_{5}>0, X_{6}>0$

Where; $\mathrm{Y}_{\mathrm{j}}$ is annual sawnwood output $\mathrm{m}^{3}$ for a single shift operation of between $6-8$

hours of production; $\mathrm{J}$ is $1,2,3$,

170 sawmills; $X_{1}$ is sawmill Land area (Hectares); $\mathrm{X}_{2}$ is labour used per annum (hours); $\mathrm{X}_{3}$ is sawlog processed per annum $\left(\mathrm{m}^{3}\right) ; \mathrm{X}_{4}$ is electricity consumed per annum at the mill $(\mathrm{Kwh}) ; \mathrm{X}_{5}$ is diesel consumed per annum (Liters); $\mathrm{X}_{6}$ is capital consumed in the production process per annum (Annual depreciation of equipment and sawmill building/shed and administrative expenses in Naira, $\mathbb{N}$ ); $\beta$ is regression coefficients of inputs (input elasticities) and $e_{i}$ is the error term.

In other to derive the corresponding self dual cost frontier which from the Cobb Douglas production functional form in equation (2) Sharma et al. (1999) suggests that the resulting equation be written in the general form;

$$
\mathrm{TC}=\mathrm{h}(\mathrm{P}, \mathrm{Y} ; \Omega)
$$

From equation (3), Shephard lemma suggested that a system of minimum cost input demand equation can be expressed as

$\partial \mathrm{TC}_{\mathrm{i}} / \partial \mathrm{P}_{\mathrm{i}}=\mathrm{X}_{\mathrm{i}}(\mathrm{Pi}, \mathrm{Yi}, \Psi) \ldots$

$\mathrm{Ln} \mathrm{TC}=\ln \mathrm{TC}(\mathrm{P}, \mathrm{Y}, \Psi)+\mathrm{W}$

$\mathrm{W}=\mathrm{V}+\mathrm{U}$

Prices of input and output are substituted into equation 4 and the firm level allocative efficiency is derived from $U$ the one-sided inefficiency component. In equation 5, TC is the minimum total cost associated with the production of sawnwood output $\mathrm{Y}, \mathrm{P}$ is a vector of input prices, and $\Psi$ is a vector of parameters, $w$ is the disturbance term which can be split into $\mathrm{V}$ which is a two sided disturbance term and $U$ which is as earlier defined. The explicit form is written as

$\mathrm{Ln} \mathrm{TC}=\Psi_{0}+\Psi_{1} \mathrm{LnP}_{\mathrm{X} 1}+\Psi_{2} \mathrm{LnP}_{\mathrm{X} 2}+\Psi_{3} \mathrm{LnP}_{\mathrm{X} 3}+$ $\Psi_{4} \mathrm{LnP}_{\mathrm{X} 4}+\Psi_{5} \mathrm{LnP}_{\mathrm{x} 5}+\Psi \mathrm{LnY}+\mathrm{W}_{\mathrm{i}} \ldots \ldots \ldots \ldots \ldots \ldots . . . \ldots$ (6) $\mathrm{P}_{1}>0, \mathrm{P}_{2}>0, \mathrm{P}_{3}>0, \mathrm{P}_{5}>0, \mathrm{P}_{6}>0$

Where; ${ }^{\mathrm{T}} \mathrm{C}_{\mathrm{i}}$ is annual total cost of producing sawnwood of the $i_{\text {th }}$ sawmill (N) for a single shift operation of between $6-8$ hours of production; $\mathrm{P}_{\mathrm{X} 1}$ is annual lease price of land per hectare (A); $\mathrm{P}_{\mathrm{X} 2}$ is price of labour per hour $(\mathrm{N}) ; \mathrm{P}_{\mathrm{X} 3}$ is price of sawlog/ $\mathrm{m}^{3}(\mathrm{~N}) ; \quad \mathrm{P}_{\mathrm{X} 5}$ is price of diesel per liter $(\mathrm{N})$; $\mathrm{Px}_{6}$ is capital (annual depreciation of equipment and sawmill building/shed and administrative expenses estimated in $\mathrm{A}$ ); $\mathrm{Y}$ is annual sawnwood output $\left(\mathrm{m}^{3}\right) ; \mathrm{w}_{\mathrm{i}}$ is error term and $\Psi$ is the regression coefficient of input price.

According to Jondrow et al. (1982), the 
estimation of individual firm level technical efficiency from equation (1) requires the measurement of the non-negative error $U$ i.e. decomposing $\mu_{t}$ into individual component $U_{t}^{t}$ and $\mathrm{V}_{\mathrm{t}}\left(\mu \mathrm{t}=\mathrm{U}_{\mathrm{t}}-\mathrm{V}_{\mathrm{t}}\right)$. The maximum likelihood estimates of the parameters of the model is obtained in terms of the parameterization $\sigma^{2}=\sigma^{2}{ }_{u}+\sigma^{2}$ and $\lambda$. The estimate of $U_{t}$ is therefore obtained by replacing $\mu \mathrm{t}$ by the residual and the unknown parameters $\sigma^{*}, \sigma^{2}$ and $\lambda=\sigma_{u} / \sigma_{y}$ by their estimates. The sawmill specific technical efficiency T.E $E_{j}$ of the $j_{\text {th }}$ sawmill was estimated to be the expected value of $U_{j}$ conditional on the random variable $\mu_{j}$ as shown by Battesse and Coelli (1988).

That is, T.E $=\exp \left(-U_{i}\right)$.

Jondrow et al. (1982) expresses the allocative efficiency of the $j_{\text {th }}$ sawmill (A.E ) obtained from the non-negative random variable $\mathrm{U}_{\mathrm{j}}$ from equation 5 as;

$A E_{j}=\exp \left(-U_{j}\right)$

Note that the two efficiency indices, the Technical efficiency (TE) and the Allocative efficiency (AE) can be combined to give the economic efficiency index.

$\mathrm{EE}=(\mathrm{TE}) *(\mathrm{AE})$

Determinants of Technical, Allocative and Economic Inefficiencies of Sawmills: In line with Ray (1988) and Sharma et al. (1999), the determinants of technical, allocative and economic inefficiency can be estimated as

$\mathrm{U}_{\mathrm{it}}=\delta_{0}+\delta_{\mathrm{i}} \mathrm{Z}_{\mathrm{i}}$.

Where $U_{\text {it }}$ is technical, allocative and economic efficiency, $Z_{\text {its }}$ are the vectors of explanatory variables associated with technical, allocative and economic inefficiencies, $\mathrm{d}_{\mathrm{is}}$ are vectors of unknown parameters to be estimated. An explicit equation can be expressed as

$\mathrm{U}_{\mathrm{it}}=\delta_{0}+\delta_{1} \mathrm{Z}_{\mathrm{i} 1}+\delta_{2} \mathrm{Z}_{\mathrm{i} 2}+\delta_{3} \mathrm{Z}_{\mathrm{i} 3}+\delta_{4} \mathrm{Z}_{\mathrm{i} 4}+\delta_{5} \mathrm{Z}_{\mathrm{i} 5}+$

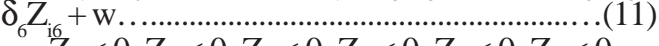

$\mathrm{Z}_{1}<0, \mathrm{Z}_{2}<0, \mathrm{Z}_{3}<0, \mathrm{Z}_{4}<0, \mathrm{Z}_{5}<0, \mathrm{Z}_{6}<0$

Where Uit and $\delta$ is areas earlier defined; $Z_{1}$ (AGE) = age in years of sawmill owner/ manager; $\mathrm{Z}_{2}$ (MGMTTYPE) is a dummy variable representing management type; Owner managed sawmills are represented as 1 while others are represented as $0 ; Z_{3}$ (EDUC) is level of education of sawmill owner/ manager in years; $\mathrm{Z}_{4}$ (YRSSAW) is length of years in sawmilling of the owner; $Z_{5}$ (CAPBASE) is value of fixed assets in Naira (building and equipment) using straight line depreciation method; $Z_{6}$ (CAPUTLZN) is capacity utilization of sawmill estimated as the ratio of observed sawnwood output to the output operator consider as their feasible maximum mill output (Beak 1997) and $w$ is the error term.

\section{RESULTS}

\section{Technical Efficiency of Sawmills in Ondo and Osun States}

From Table 1, the OLS estimates of the coefficients of sawlog in both Ondo and Osun states are significant at $1 \%$. These portray sawlog as a very important input in sawnwood production for sawmills. This underscores why sawlog needs to be used efficiently at sawmills. The coefficients of sawlog in Ondo and Osun states indicate that a $100 \%$ increase in sawlog at sawmill result in a $95.53 \%$ increase in sawnwod output, while a $100 \%$ increase in sawlog result in a $100 \%$ increase in sawnwood output in Ondo and Osun states, respectively. These results also indicate high factor intensity for sawlog and emphasize the need for great caution in the use of this input since it takes about a felling cycle of 50 years for most timber species to arrive at a merchantable size (Dykstra et al. 1996). The coefficient of electricity is significant at $10 \%$ for sawmills in Ondo state indicating the importance of electricity in determining sawnwood output in this state. This result clearly justifies government's policies of deregulating the energy sector in Nigeria, which should be given wholehearted support. This will in the long run help to achieve constant electricity supply which is an important source of energy in sawnwood production. Furthermore an adjusted $\mathrm{R}^{2}$ of 0.72 and 0.87 imply that the production inputs jointly explain $72 \%$ and $87 \%$ of the variations in sawnwood output in Ondo and Osun states, respectively. From the maximum likelihood estimates (Table 1) scale coefficients of 1.18 and 1.93 indicates increasing returns to scale which implies that there are potential for sawmills in both states to continue to expand sawnwood output because they are yet to reach the minimum points of their long run average cost curve which is the best point for them to produce.

The diagnostic statistics of the inefficiency components in Ondo and Osun states, reveal that sigma squared $\left(\sigma_{\mathrm{S}}^{2}\right)$ is statistically significant at $1 \%$. These indicate goodness of fit, and the correctness of the distributional form assumed for the composite error term. Lambda $(\lambda)$ is significant at $5 \%$ and greater than one in both states, implying that the one-sided error term $U$ 
dominates the symmetric error V. It also indicates a good fit and correctness of the specified distribution form (Tadesse and Moorthy 1997). The technical efficiency distribution indices (Table 2) indicate that the largest efficiency group for sawmills, that is, $26.51 \%$ of sawmills operate between $71 \%$ and $80 \%$ while $37.93 \%$ of sawmills fall between $81 \%$ and $90 \%$ in Ondo and Osun states, respectively. This is fairly high but sawmillers still have the potential to further increase their efficiency levels.

\section{Allocative Efficiency of sawmills in Ondo and Osun states}

From the OLS estimate of the cost function (Table 3), the coefficients of the prices of capital, and sawnwood output are significant for sawmills in Ondo state at $1 \%$ while none of the variables is significant in Osun state. This implies that sawmills in Ondo state are very sensitive to price of capital. If the price of capital is increased by $100 \%$ total cost of production is increased by

Table 1: Ordinary least squares (OLS) estimates of the average production function and Maximum Likelihood (ML) estimate of stochastic production frontier for sawmillers in Ondo and Osun State

\begin{tabular}{|c|c|c|c|c|c|c|c|c|}
\hline \multirow{3}{*}{ Variable } & \multicolumn{4}{|c|}{ Ondo State } & \multicolumn{4}{|c|}{ Osun State } \\
\hline & \multicolumn{2}{|c|}{ OLS estimate } & \multicolumn{2}{|c|}{ ML estimate } & \multicolumn{2}{|c|}{ OLS estimate } & \multicolumn{2}{|l|}{ ML estimate } \\
\hline & Coefficient & $\begin{array}{l}\text { Standard } \\
\text { error }\end{array}$ & Coefficients & $\begin{array}{c}\text { Standard } \\
\text { error }\end{array}$ & Coefficient & $\begin{array}{l}\text { Standard } \\
\text { error }\end{array}$ & Coefficient & $\begin{array}{l}\text { Standard } \\
\text { error }\end{array}$ \\
\hline Constant & -2.0360 & 3.7768 & 0.3751 & 3.9809 & 1.7279 & 1.7151 & 1.0096 & 1.7332 \\
\hline Ln $X_{1}$ (Land) & 0.1063 & 0.2092 & 0.0039 & 0.1595 & 0.0644 & 0.0989 & 0.0350 & 0.0857 \\
\hline Ln $X_{2}^{1}$ (Labour) & 0.2430 & 0.3104 & 0.2080 & 0.3864 & -0.0668 & 0.1070 & 0.0392 & 0.1541 \\
\hline Ln $X_{3}^{2}$ (Sawlog) & $0.9553 * * *$ & 0.2049 & $0.8575 * * *$ & 0.2137 & $1.0000 * * *$ & 0.0730 & $0.9725 * * *$ & 0.0926 \\
\hline Ln $\mathrm{X}_{4}^{3}$ (Electricity) & $-0.4349 * *$ & 0.1624 & -0.2640 & 0.1897 & 0.0287 & 0.0648 & 0.0082 & 0.0745 \\
\hline Ln $X_{5}($ Diesel $)$ & -0.1145 & 0.1571 & -0.1116 & 0.1741 & -0.0588 & 0.0725 & -0.0339 & 0.0782 \\
\hline Ln $\mathrm{X}_{6}^{5}$ ( Capital) & 0.3100 & 0.3228 & 0.1360 & 0.3861 & -0.0986 & 0.1531 & -0.0960 & 0.1479 \\
\hline Adjusted $\mathrm{R}^{2}$ & 0.7196 & & & & 0.8771 & & & \\
\hline F Statistics & $36.08 * * *$ & & & & $103.24 * * *$ & & & \\
\hline$\sigma_{\mathrm{S}}^{2}=\sigma_{\mathrm{v}}^{2}+\sigma^{2}$ & & & $0.6421 * * *$ & 0.0778 & & & $0.3355 * * *$ & 0.0392 \\
\hline$\lambda=\sigma / \sigma_{\mathrm{v}}$ & & & $3.9947 *$ & 1.8122 & & & $3.3279 *$ & 1.3851 \\
\hline \multicolumn{9}{|l|}{ Quasi function } \\
\hline Coefficient & & & 1.1805 & & & & 1.9346 & \\
\hline Log likelihood & & & - 38.0684 & & & & 14.1277 & \\
\hline
\end{tabular}

Source: Computed from field survey data, 2003.

$* * *$ Significant at $1 \%$ level and ** Significant at $5 \% \& *$ Significant at $10 \%$

Table 2: Technical efficiency distribution of sawmills in Ondo and Osun states

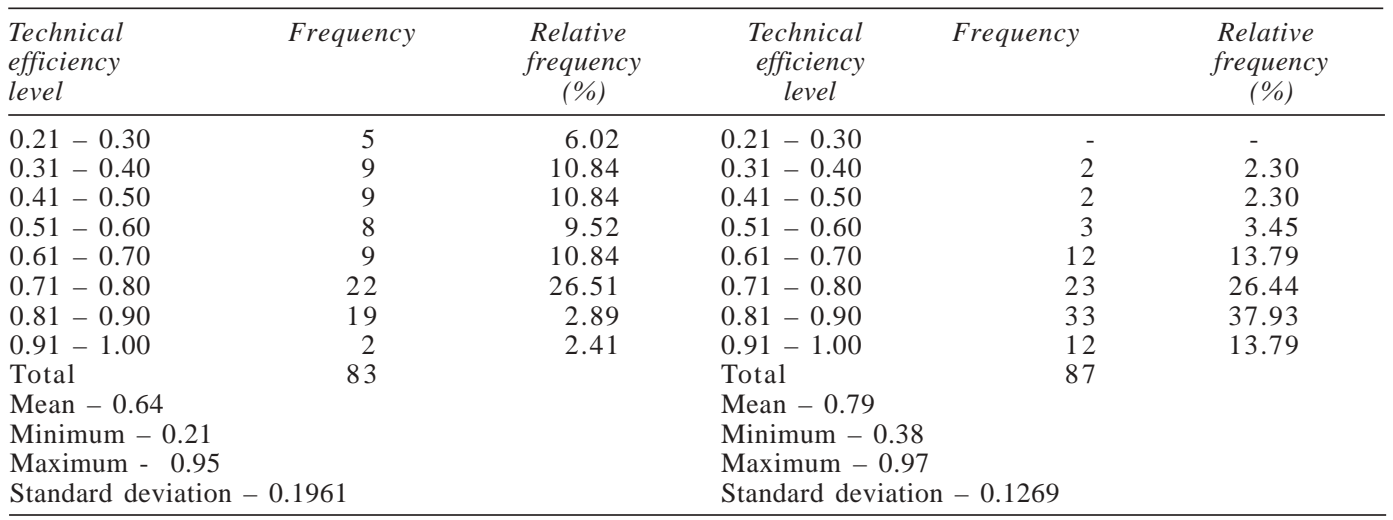

Source: Computed from survey data, 2003.

Percentage distribution of efficiency levels in parentheses 
$100 \%$. This indicates that, sawmillers may need to avoid working with funds higher than the opportunity cost of capital of $21 \%$, which was the prevailing lending rate at commercial banks in Ondo state at the time of study. This interest rate has the tendency to increase total cost of production. Similarly, if sawnwood output is increased by $100 \%$, total cost of production is increased by $27.31 \%$. However an increase in sawnwood output may not result in an increase in total cost of production if the increase is generated by an efficient use of the presently available production inputs. From Table 3, adjusted $\mathrm{R}^{2}$ of 0.8290 and 0.917 in Ondo and Osun states imply that the price per unit of the production inputs and sawnwood output jointly explains $82.90 \%$ and $91.70 \%$ of the variations in total cost of producing sawnwood at sawmills in Ondo and Osun states, respectively.

Tables 4 show that the mean allocative efficiency of sawmills in Ondo and Osun states are 81 and $83 \%$. These values are quite high and indicate that sawmillers have put to bear the understanding of the sawmill business by being able to allocate resources fairly well. Nevertheless, there is need to improve on the present level of allocative efficiency. Going by the estimated allocative efficiency level, sawmills in Ondo and Osun states can save $19 \%$ and $17 \%$ of their present cost by behaving in a cost minimizing

Table 3: Ordinary least squares (OLS) estimates of the average cost function and Maximum Likelihood (ML) estimate of stochastic cost frontier for sawmillers in Ondo and Osun states

\begin{tabular}{|c|c|c|c|c|c|c|c|c|}
\hline \multirow{3}{*}{ Variable } & \multicolumn{4}{|c|}{ Ondo State } & \multicolumn{4}{|c|}{ Osun State } \\
\hline & \multicolumn{2}{|c|}{ OLS estimate } & \multicolumn{2}{|c|}{ ML estimate } & \multicolumn{2}{|c|}{ OLS estimate } & \multicolumn{2}{|l|}{ ML estimate } \\
\hline & Coefficient & $\begin{array}{c}\text { Standard } \\
\text { error }\end{array}$ & Coefficients & $\begin{array}{l}\text { Standard } \\
\text { error }\end{array}$ & Coefficient & $\begin{array}{c}\text { Standard } \\
\text { error }\end{array}$ & Coefficient & $\begin{array}{l}\text { Standard } \\
\text { error }\end{array}$ \\
\hline Constant & -5.2616 & 5.9694 & -4.7634 & 5.9348 & -0.9250 & 3.5855 & -2.9442 & 3.2378 \\
\hline $\operatorname{Ln} X_{1 \mathrm{P}}($ Land $) \mathrm{A}$ & 0.3224 & 0.3600 & 0.3222 & 0.3420 & -0.0554 & 0.2150 & 0.0785 & 0.1836 \\
\hline Ln $X_{2 \mathrm{P}}^{\mathrm{TP}}$ (Labour) $\mathrm{N}$ & -0.5717 & 0.3684 & -0.4635 & 0.4319 & -0.3055 & 0.2024 & -0.1805 & 0.2346 \\
\hline $\operatorname{Ln} X_{3 P}^{2 P}($ Sawlog $) A$ & 0.5197 & 0.3426 & 0.3405 & 0.4000 & 0.9853 & 0.1471 & $0.9962 * * *$ & 0.1668 \\
\hline $\operatorname{Ln} X_{5 P}^{3 P}($ Diesel $) A$ & 0.5621 & 0.5719 & 0.5918 & 0.7341 & 0.2595 & 0.4057 & 0.4155 & 0.4228 \\
\hline Ln $X_{6 \mathrm{P}}^{5 \mathrm{P}}$ (Capital) $\mathrm{N}$ & $1.0014 * * *$ & 0.1294 & $1.0127 * * *$ & 0.1013 & 0.4898 & 0.0901 & $0.4111 * * *$ & 0.1092 \\
\hline $\begin{array}{l}\text { Ln Y } \\
\text { (Sawnwood output } \\
\mathrm{m}^{3}\end{array}$ & ut) $0.2731 * * *$ & 0.0511 & $0.2807 * * *$ & 0.0496 & 0.5738 & 0.0429 & $0.6084 * * *$ & 0.0386 \\
\hline Adjusted $\mathrm{R}^{2}$ & 0.8292 & & & & 0.9173 & & & \\
\hline F Statistics & $67.33 * * *$ & & & & $160.01 * * *$ & & & \\
\hline$\sigma_{\mathrm{S}}^{2}=\sigma_{\mathrm{V}}^{2}+\sigma^{2}$ & & & $0.3040 * * *$ & 0.0304 & & & $0.2518 * * *$ & 0.0288 \\
\hline$\lambda \stackrel{s}{=} \sigma / \sigma_{\mathrm{v}}$ & & & $2.1094^{*}$ & 0.7454 & & & $3.8466 *$ & 1.6569 \\
\hline Log likelihood & & & 13.4616 & & & & 41.1417 & \\
\hline
\end{tabular}

Source: Computed from field survey data, 2003.

*** Significant at $1 \%$, **Significant at $5 \%$ \& Significant at $10 \%$

Table 4: Allocative efficiency distribution of sawmills in Ondo and Osun states

\begin{tabular}{|c|c|c|c|c|c|}
\hline $\begin{array}{l}\text { Allocative } \\
\text { efficiency } \\
\text { level }\end{array}$ & Frequency & $\begin{array}{c}\text { Relative } \\
\text { frequency } \\
(\%)\end{array}$ & $\begin{array}{c}\text { Allocative } \\
\text { efficiency } \\
\text { level }\end{array}$ & Frequency & $\begin{array}{l}\text { Relative } \\
\text { frequency } \\
(\%)\end{array}$ \\
\hline $0.31-0.40$ & 1 & 1.21 & - & - & - \\
\hline $0.41-0.50$ & - & - & - & - & - \\
\hline $0.51-0.60$ & 2 & 2.41 & $0.51-0.60$ & 3 & 3.45 \\
\hline $0.61-0.70$ & 6 & 7.23 & $0.61-0.70$ & 8 & 9.20 \\
\hline $0.71-0.80$ & 24 & 28.92 & $0.71-0.80$ & 21 & 24.14 \\
\hline $0.81-0.90$ & 38 & 45.78 & $0.81-0.90$ & 27 & 31.03 \\
\hline $0.91-1.00$ & 12 & 14.46 & $0.91-1.00$ & 28 & 32.18 \\
\hline Total & 83 & & Total & 87 & \\
\hline \multicolumn{3}{|l|}{ Mean - 0.81} & \multicolumn{3}{|l|}{ Mean -0.83} \\
\hline \multicolumn{3}{|l|}{ Minimum -0.38} & \multicolumn{3}{|c|}{ Minimum -0.52} \\
\hline \multicolumn{3}{|c|}{ Maximum - 0.98} & \multicolumn{3}{|c|}{ Maximum - 0.97} \\
\hline \multicolumn{3}{|c|}{ Standard deviation - 0.0992} & \multicolumn{3}{|c|}{ Standard deviation -0.1065} \\
\hline
\end{tabular}

Source: Computed from survey data, 2003.

Percentage distribution of efficiency levels in parentheses 
way. Put in another way, sawmills in these states have increased their costs by $19 \%$ and $17 \%$ due to allocative inefficiency.

\section{Economic Efficiency of Sawmills in Ondo and Osun States}

Tables 5 reveals that sawmills in Ondo and Osun states have mean economic efficiency values of $54 \%$ and $67 \%$, respectively. It can be inferred that if sawmills in Ondo and Osun states, will achieve $100 \%$ economic efficiency, they would experience substantial production cost saving of $46 \%$ and $37 \%$, respectively. In both states, there is need to improve their economic efficiency levels. Furthermore, the largest groups of sawmills have economic efficiency levels of between $61-70 \%$ and $81 \%$ and $90 \%$, respectively in Ondo and Osun states, respectively.

\section{Determinants of Technical, Allocative and Economic Inefficiencies of Sawmills in Ondo and Osun States}

The OLS estimate of the factors affecting the technical, allocative and economic inefficiencies of sawmillers in Ondo and Osun states are shown in Table 6 and 7. The coefficient of capital base positively and significantly influenced technical, allocative and economic inefficiencies of sawmills in Ondo state at $1 \%$. The result implies that for sawmills in Ondo state, an increase in capital base results in an increase in technical, allocative and economic inefficiencies. This is contrary to a priori theoretical expectation and may be because the prevailing interest rate of $21 \%$ is too high or that sawmills are presently overcapitalized. Furthermore the coefficients of capacity utilization have positive and statistically significant relationship with technical inefficiency at $1 \%$ contrary to a priori theoretical expectation. Furthermore, the adjusted $\mathrm{R}^{2}$ shows that the inefficiency determinants explain $82.55 \%, 21.77 \%$ and $72.95 \%$ variations in the technical, allocative and economic inefficiencies of sawmillers in Ondo state. Also, Table 7 reveals that the coefficient of capital base is negative and significant at $5 \%$. This is consistent with a priori expectation. This indicates that as capital base increases, allocative inefficiency of sawmill in Osun state reduces. This may requires that sawmillers seek alternative sources of securing credit to augment their requirement and capital base. This would enable them acquire more secondary wood processing equipment most especially circular saw and planning machines in other to enable them utilize the slabs and wood chunks arising from primary wood conversion.

The coefficients of capacity utilization have negative and statistically significant relationship with technical, allocative and economic inefficiencies at $1 \%$. This agrees with a priori theoretical expectation. This implies that as capacity utilization increases technical, allocative and economic inefficiency reduce. Further, the adjusted $\mathrm{R}^{2}$ shows that the inefficiency

Table 5: Economic efficiency distribution of sawmills in Ondo and Osun states

\begin{tabular}{|c|c|c|c|c|c|}
\hline $\begin{array}{l}\text { Economic } \\
\text { efficiency } \\
\text { level }\end{array}$ & Frequency & $\begin{array}{l}\text { Relative } \\
\text { frequency } \\
\quad(\%)\end{array}$ & $\begin{array}{c}\text { Economic } \\
\text { efficiency } \\
\text { level }\end{array}$ & Frequency & $\begin{array}{c}\text { Relative } \\
\text { frequency } \\
(\%)\end{array}$ \\
\hline $0.01-0.10$ & 1 & 1.20 & & & \\
\hline $0.11-0.20$ & 2 & 2.41 & $0.11-0.20$ & 1 & 1.15 \\
\hline $0.21-0.30$ & 10 & 12.05 & $0.21-0.30$ & 2 & 2.30 \\
\hline $0.31-0.40$ & 11 & 13.25 & $0.31-0.40$ & 6 & 6.90 \\
\hline $0.41-0.50$ & 7 & 8.43 & $0.41-0.50$ & 5 & 5.75 \\
\hline $0.51-0.60$ & 15 & 18.07 & $0.51-0.60$ & 14 & 16.09 \\
\hline $0.61-0.70$ & 19 & 22.89 & $0.61-0.70$ & 17 & 19.54 \\
\hline $0.71-0.80$ & 14 & 16.87 & $0.71-0.80$ & 19 & 21.84 \\
\hline \multirow[t]{2}{*}{$0.81-0.90$} & 4 & 4.82 & $0.81-0.90$ & 20 & 22.99 \\
\hline & & & $0.91-1.00$ & 3 & 3.45 \\
\hline Total & 83 & & Total & 87 & \\
\hline Mean -0.54 & & & Mean -0.67 & & \\
\hline Minimum -0.08 & & & Minimum - & & \\
\hline Maximum - 0.90 & & & Maximum - & & \\
\hline Standard deviation & 0.1891 & & Standard dev & -0.1712 & \\
\hline
\end{tabular}

Source: Computed from survey data, 2003.

Percentage distribution of efficiency levels in parentheses 
Table 6: Determinants of technical, allocative and economic inefficiencies of sawmillers in Ondo state

\begin{tabular}{lcccc}
\hline Variable & Mean & $T E$ & $A E$ & $E E$ \\
\hline Constant & - & $1.0009 * * *$ & $1.4384 * * *$ & $1.1850 * * *$ \\
AGE & 52.29 & 0.0326 & -0.0948 & -0.0337 \\
MGTTYPE & 0.42 & $-0.0492 *$ & $-0.0543 *$ & $-0.0676 *$ \\
EDUC & 11.42 & -0.0159 & -0.0535 & -0.0420 \\
YRSSAW & 14.25 & -0.0132 & $0.0431 * *$ & 0.0407 \\
CAPBASE & 8.73 & $0.3622 * * *$ & $0.0699 * * *$ & $0.3247 * * *$ \\
CAPUTLZN & & $0.8255^{*} *$ & 0.2177 & 0.7295 \\
Adjusted R & & 0.8255 & 0.2177 & 0.7295 \\
F & & $65.68 * * *$ & $4.80 * * *$ & $37.86 * *$ \\
\hline
\end{tabular}

Source: Computed from survey data, 2003

$* * *$ Significant at $1 \%, *$ Significant at $5 \%$ and $* *$ Significant at $10 \%$

Table 7: Determinants of technical, allocative and economic inefficiencies of sawmillers in Osun states

\begin{tabular}{lcccc}
\hline Variable & Mean & $T E$ & $A E$ & $E E$ \\
\hline Constant & - & $1.2398^{* * *}$ & $1.2688^{* * *}$ & $1.3092^{* * *}$ \\
AGE & 51.47 & 0.0098 & -0.0182 & 0.0076 \\
MGTTYPE & 0.43 & -0.0143 & -0.0441 & -0.0413 \\
EDUC & 10.55 & -0.0217 & -0.0122 & -0.0311 \\
YRSSAW & 12.20 & -0.0194 & 0.0084 & -0.0129 \\
CAPBASE & 7.20 & -0.0125 & $-0.0596^{*}$ & -0.0600 \\
CAPUTLZN & & $0.2947 * * *$ & $-0.1831^{* * *}$ & $-0.3550^{* * *}$ \\
Adjusted R & & 0.4393 & 0.2865 & 0.3532 \\
F & & $12.23^{2} * *$ & $12.23^{* * *}$ & $8.83^{* * *}$ \\
\hline
\end{tabular}

Source: Computed from survey data, 2003

*** Significant at $1 \%$ and $*$ Significant at $5 \%$.

determinants explain $43.93 \%, 28.65 \%$ and $35.32 \%$ variations in the technical, allocative and economic inefficiencies of sawmillers in Osun state.

\section{CONCLUSION AND RECOMMENDATIONS}

\section{Policy Implications of Empirical Result and Recommendations}

Arising from the major findings the following policy implications are drawn;

On average sawmills in Ondo and Osun states have high technical, allocative and economic efficiencies. In both states, sawmills have potential to either increase output using the same level of input or reduce the present level of input use for the same level output. The fact that sawmills in both states operate at decreasing returns to scale necessitates that they should maintain the present level of input use and expand sawnwood output. Also, sawmills in both states are more allocatively than technically efficient. An increase in economic efficiency could therefore be better achieved by improving technical efficiency. This would involve maximally utilizing production inputs especially sawlog and electricity for sawmills in Ondo state, while sawlog, for sawmills in Osun state. This suggests that assistance such as credit for expansion and the procurement of secondary processing wood equipment that will enhance sawlog utilization is necessary; likewise, is the issue of steady public electricity supply to sawmills.

- Apart from reorganizing production inputs, other managerial precautions are relevant. In Ondo state, sawmill owners may need to be more committed to the issue of managing their sawmills, this will reduce technical, allocative and economic inefficiency. An increase in capital base through acquisition of secondary wood processing equipment will reduce technical, allocative and economic inefficiencies in Ondo state, while this will reduce allocative efficiency in Osun state. Further, sawmillers in Ondo state need to improve on their present level of capacity utilization to be able to reduce technical inefficiencies while those in Osun state would achieve the same so as to reduce technical, allocative and economic inefficiencies. This will require that sawmillers improve on the 
utilization of sawlog at sawmills. However if this is addressed through increasing the supply of sawlog to sawmills then, concerted effort may need to be put in place to replant harvested forest areas; otherwise the negative consequences of deforestation cannot be escaped.

Arising from the following discussions the study recommends that sawmillers should make effort to improve the efficiency level of their mills; improve their managerial ability through relevant trainings; strengthen their capital base and government should show great commitment to the deregulation of the energy sector in Nigeria.

\section{REFERENCES}

Aigner DJ, Lovell CAK, Schmidt P 1977. Formulation and estimation of stochastic frontier production models. Journal of Econometrics, 6: $21-37$.

Battese G.E, Coelli TJ 1988. Prediction of firm level technical efficiencies with a genaralized frontier production function and panel data. Journal of Econometrics, 38: 387-399.

Beak Consultants Ltd 1997. Pricing Policies and Market Assesment. Final Report.Forest Resources Study, Nigeria'. Presented to FORMECU, Abuja, Nigeria.

Bravo- Ureta BE, Evenson ER 1994. Efficiency in agricultural production: The case of peasant farmers in eastern Paraguay. Journal of Agricultural Economics, 10(1): 27-37.

Chavas J, Aliber M 1993. An analysis of economic efficiency in agriculture: A nonparametric approach. Journal of Agricultural and Resource Economics, 8(1): 1-16.

Dykstra DP, Kowero GS, Ofosu -Asiedu A, Rio P 1996. Promoting Stewardship of Forest in the Humid Forest Zone of Anglophone West and Central Africa. The United Nations Environment Programmme and the Centre of International Forestry Research. Final Report, 103 pp.

Farrell MJ 1957. The measurement of production efficiency. Journal of the Royal Statistical. Society, 120A: 257-281.
Farrell MJ, Fieldhouse M 1962. Estimating efficient production under increasing returns to scale. Journal of the Royal Statistical Society, Series A 125: 252 267.

HM Gunatilake, Gunaratne LHP 2002. Policy option for conserving Sri Lanka's natural forests" www.crdi.ca/iicr/ev-24233-201-1-DO_TOPIC.html.

Jondrow JC, Lovell AK, Materov IS, Schmidt P 1982. On the estimation of technical inefficiency in the stochastic frontier production function model. Journal of Econometrics, 19: 233 - 238.

Kopp RJ, Smith VK 1980. Frontier production function estimates of steam electric generation: a comprrative analysis. South Econ J, 44: 1049 - 1059.

Noack D 1995. Making better use of tropical timber resource. ITTO, Tropical Forest Update, 5(2): 1213.

Shafiq M, Rehman T 2000. The extent of resource use in efficiencies in cotton producton in Pakistan's Punjab: An application of data envelopment analysis. Agricultural Economics, 22(3): 321 - 330.

Ray S 1988. Data envelopment analysis, non discretionary inputs and efficiency: An alternative interpretation. Socio- Econom Plann Sci, 22: 167 - 176.

Sharma KRP, Leung P, Zaleski HM 1999. Technical, allocative and economic efficiencies in swine production in Hawaii: A comparison of parametric and nonparametric approaches. Agricultural Economics, 20: 23-35.

Tadesse B, Moorthy SK 1997. Technical efficiency in paddy farms of Tamil Nadu: An analysis based on farm size and ecological zone. Agricultural Economics, 16: 185 - 192.

Ondo State Ministry of Finance 2000. Digest of Demographic Statistics.

Meeusen W, Van den Broeck J 1977. Efficiency estimation from Cobb Douglas production functions with Composed Error. International Economic Review, 18: 435 - 444.

Olaseni O, Agbeja BO, Adeyoju SK 2004. Dynamics of forest revenue collection and forestry development in Ondo State (1991 - 2000). Bowen Journal of Agriculture, 1(1): 43 -51.

Zellener A, Kmenta J, and Dreze J 1966. Specification and estimation of Cobb Douglas production function models. Econometrica, 34: $784-795$. 